\title{
ROLA POAKCESYJNYCH MIGRACJI ZAGRANICZNYCH W ZMIANACH PRZESTRZENNYCH UKŁADÓW ZALUDNIENIA W POLSCE W LATACH 2004-2012
}

\author{
THE INFLUENCE OF POST-ACCESSION MIGRATION ABROAD \\ ON THE CHANGES IN THE TERRITORIAL POPULATION SYSTEMS \\ IN POLAND IN THE YEARS 2004-2012
}

\begin{abstract}
Nr DOI: $10.25167 / \mathrm{sm} 2018.029 .03 \quad$ s. $45-60$
ABSTRAKT: Poakcesyjne migracje Polaków były jednym z ważniejszych wydarzeń w najnowszej historii Polski. Po 2004 r. Polacy masowo wyjeżdżali do Wielkiej Brytanii i Irlandii, które jako jedne z pierwszych zliberalizowały dostęp do swoich rynków pracy dla obywateli nowych krajów członkowskich Unii Europejskiej. Celem pracy jest ukazanie wpływu poakcesyjnych migracji zagranicznych ludności na zmiany demograficznych układów zaludnienia w Polsce w latach 2004-2012. W pracy wykorzystano dane pochodzące z Głównego Urzędu Statystycznego dotyczące wyjazdów na pobyt czasowy i stały w latach 2004-2012. Z badań wynika, że poakcesyjne migracje miały wpływ na zmiany demograficzne Polski. Depopulacja spowodowana emigracją występowała nie tylko w województwie opolskim, ale także w innych rejonach kraju (gminy wiejskie w województwach dolnośląskim i śląskim, a także gminy położone poza strefą oddziaływania dużych miast, głównie w województwach: świętokrzyskim, lubelskim i podlaskim). Z kolei korzystny wpływ poakcesyjnych migracji odnotowano w gminach wokół dużych miast, w których następował przyrost ludności. Warto dodać, że migracje zagraniczne odegrały mniejszą rolę w kreowaniu zaludnienia w województwach, gdzie ludność preferuje tradycyjny model rodziny (np. województwo małopolskie), oraz w gminach województw wielkopolskiego i pomorskiego.
\end{abstract}

SŁOWA KLUCZOWE: poakcesyjne migracje Polaków, zmiany demograficzne w Polsce, migracje w Polsce, międzynarodowe migracje w Polsce, typologia migracji w Polsce.

ABSTRACT: Post-accession migration of Poles was one of the most important phenomena in recent history of Poland. After 2004, Poles were leaving mainly for the UK and Ireland, which were the first countries to relax their regulations of the labour market for citizens of new member states. The aim of the study is to show the impact of the post-accession migration on the changes in the demographics systems of population in Poland in the years 2004-2012. The study uses data from the Central Statistical Office, which concerned emigration with temporary residence and permanent residence in the years 2004-2012. The study shows that international migration of Poles has a significant impact on the demographic situation in Poland. The research shows that population loss occurs not only in Opolskie Province, which is considered to be strongly affected by emigration, but also in other areas of the country (rural communities in the Dolnośląskie and

*Uniwersytet Jagielloński, Instytut Geografii i Gospodarki Przestrzennej, e-mail: jadwiga.galka@uj.edu.pl. 
Śląskie Provinces, also in the municipalities outside the influence zone of the capital cities in the provinces of Świętokrzyskie, Lubelskie and Podlaskie). In contrast, the situation was favourable in the influence zones of large cities. In addition, migration abroad proved to be of small significance in regions with the traditional family-based model, such as Małopolska Province and in the municipalities in Wielkopolska and Pomorskie Provinces.

KEY WORDS: post-accession migration of Poles, population changes in Poland, demographic changes in Poland, migration in Poland, international migration in Poland, migration typology in Poland

\section{Wpływ migracji na zmiany zaludnienia - stan dotychczasowych badań}

Migracje zagraniczne od stuleci wpisane są w historię Polski. W różnych okresach Polacy wyjeżdżali z kraju w celach ekonomicznych, politycznych, turystycznych czy rodzinnych. Ostatnim wydarzeniem, które w gwałtowny sposób wpłynęło na wzrost mobilności międzynarodowej Polaków, była akcesja Polski do Unii Europejskiej 1 maja 2004 r. oraz wprowadzenie ruchu bezwizowego do pozostałych krajów „starej Unii”. Liberalizacji uległy też przepisy dotyczące podejmowania pracy przez Polaków początkowo w trzech krajach: Irlandii, Szwecji i Wielkiej Brytanii, a w kolejnych latach okresy przejściowe przestały obowiązywać w pozostałych krajach, co ułatwiło migrantom podejmowanie legalnego zatrudnienia w tych krajach.

Tematyka dotycząca poakcesyjnych emigracji Polaków była często poruszana przez naukowców. Powstało wiele prac dotyczących skali emigracji zaraz po akcesji Polski do Unii Europejskiej (Iglicka, Weinar 2005) oraz charakterystyki demograficznej emigrantów. Badania te wskazywały na to, że największy odpływ na pobyt stały za granicę odnotowano dwa lata po akcesji, dominującymi kierunkami wyjazdów Polaków na pobyt czasowy oraz stały były: Wielka Brytania, Niemcy i Irlandia, a w strukturze wieku dominowały osoby w młodszym wieku produkcyjnym. Głównym motywem wyjazdów Polaków były względy ekonomiczne i chęć poprawy warunków życia (Fihel, Kaczmarczyk 2008; Gałka 2012; Kłos 2006; Zborowski, Gałka 2008). Po 2008 r., kiedy rozpoczął się kryzys ekonomiczny, a w Polsce odnotowano wzrost liczby reemigrantów, naukowcy podjęli próbę oceny planów migracyjnych rodaków. Wynika z nich, że Polacy mieszkający za granicą nie mają sprecyzowanych planów powrotu. Podejmowane decyzje o reemigracji wynikają bardziej z objętej przed wyjazdem strategii migracyjnej niż z kryzysu ekonomicznego (Hołda et al. 2011). Już badania Drinkwatera, Eadego i Garapicha w 2006 r. wykazały, że inne plany migracyjne mają migranci, którzy przyjechali do Wielkiej Brytanii z zamiarem osiedlenia się na stałe, a inne ci, którzy przyjechali w celu zdobycia środków finansowych na wybudowanie domu, zakup auta czy na studia.

Nieliczne badania pokazują, jak kształtuje się ruch migracyjny z Polski po akcesji do UE w układzie przestrzennym. Badania Długosza (2012) wykazały, że kierunki wyjazdów Polaków były zróżnicowane i wynikały z długich tradycji migracyjnych, np. z Małopolski do Austrii (Górz 1994) czy z województw opolskiego i śląskiego do Niemiec. Potwierdzeniem tych badań były prace R. Jończego i D. Rokity-Poskart (2010; 2012), dotyczące emigracji z województwa opolskiego do Niemiec. Z kolei praca E. Zdro- 
jewskiego i M. Guzińskiej wskazywała na to, że migracje zewnętrzne ludności były silnie zróżnicowane przestrzennie. Z ich badań wynika, że,,Polska na skutek migracji zagranicznych tylko w latach 1999-2006 utraciła łącznie ponad 470 tys. ludności. Na przemieszczeniach międzypaństwowych zyskały jedynie województwa: mazowieckie (97,2 tys.), małopolskie (20,6 tys.), wielkopolskie (14,9 tys.) i pomorskie (6,1 tys.). Wszystkie pozostałe województwa wykazały ujemne salda migracyjne” (Zdrojewski, Guzińska 2011).

Rola migracji w kształtowaniu przestrzennych układów zaludnienia była tematem rozważań innych naukowców, jednak analizy te prowadzono głównie na poziomie ogólnokrajowym lub wojewódzkim (Gałązka 2007; Sakson 2007; Zdrojewski 2007; 2009). Brakuje szczegółowych prac, które byłyby rozpatrywane na poziomie lokalnym (gmin).

\section{Cel, zakres czasowy i przestrzenny pracy. Dane źródłowe i metody badań}

Celem pracy jest ukazanie wpływu poakcesyjnych migracji zagranicznych ludności na zmiany regionalnych układów zaludnienia w Polsce w latach 2004-2012. W tym celu w artykule wykorzystano dane pochodzące z Głównego Urzędu Statystycznego dotyczące wyjazdów na pobyt czasowy (zasoby migracyjne) oraz na stałe w latach 2004-2012 w skali lokalnej (wg gmin). Opracowano również typogram relacji pomiędzy ruchem naturalnym a saldem migracji zewnętrznych na pobyt stały dla średniej z lat 2004-2012 oraz dodatkowo dla trzech uśrednionych podokresów różniących się liczbą emigrantów. Pierwszy okres obejmował lata 2004-2006 (największa fala wyjazdów), drugi okres obejmował lata 2007-2009 (spadek natężenia wyjazdów w czasie kryzysu ekonomicznego) i trzeci okres - lata 2010-2012 (wzmożenie emigracji po kryzysie ekonomicznym). Dzięki temu możliwe było sprawdzenie, czy zmieniająca się liczba emigrantów w kolejnych podokresach ma wpływ na zmiany ludnościowe w skali lokalnej.

Metodologia opracowanego w tym artykule typogramu ruchu naturalnego i salda migracji zewnętrznych była analogiczna jak przy konstrukcji typologii J. Webba (Holzer 2003). Tu również wyróżniono osiem typografów od A do H. Modyfikacja klasycznej typologii Webba polegała na zastąpieniu salda migracji ogółem saldem migracji zagranicznych. Analogicznie jak w procedurze Webba typy A, B, C i D oznaczają przyrost liczby ludności, natomiast E, F, G i H - ubytek liczby ludności (Jędrzejczyk 2001). Warto dodać, że szczególnie typy C i D oraz G i H informują nas o wpływie migracji na ogólny przyrost lub ubytek ludnościowy w gminie. Taki sposób konstrukcji typogramu wpłynął na wynik końcowy. Zważywszy na skalę niedoszacowania wyjazdów w skali lokalnej, rola migracji zagranicznych w kształtowaniu zaludnienia danej gminy będzie najbardziej widoczna tam, gdzie ludność dopełniła obowiązku meldunkowego oraz gdzie istniał niski przyrost naturalny. Natomiast w regionach, w których występują sezonowe migracje za granicę, migracje czasowe lub nieudokumentowane migracje długookresowe, wpływ migracji międzynarodowych będzie niewielki. Dlatego liczba typów C, D, G, i H jest zaniżona. 
Na podstawie zmian typografów w kolejnych podokresach opracowano dodatkową klasyfikację ich zmienności. W ten sposób zbadano, czy wpływ migracji na zmiany demograficzne jest widoczny we wszystkich analizowanych okresach oraz czy są pewne obszary, w których rozwój demograficzny najbardziej był uzależniony od migracji zagranicznych.

\section{Zmiany przyrostu rzeczywistego ludności w Polsce w latach 2004-2012}

W latach 2004-2012 zaobserwowano nieznaczny wzrost liczby ludności Polski. Wskaźnik dynamiki liczony względem 2004 r. wynosił ponad $100 \%$. Zaobserwowano silne dysproporcje między rozwojem demograficznym miast oraz wsi w badanych latach (ryc. 1). Liczba mieszkańców miast w badanym okresie spadła o 0,6\%, natomiast liczba ludności na terenach wiejskich wzrosła o 3,4\%. W badanym okresie wyraźnie widać wpływ przemian transformacyjnych, jakie dokonują się w Polsce od 1989 r. Zmianie uległy kierunki migracji ludności i obecnie dominuje typ przemieszczeń z miast na wieś. Jest to związanie z wejściem głównych polskich miast w fazę suburbanizacji, która w sensie demograficznym polega na spadku liczby ludności w miastach centralnych oraz jej wzrostem w strefach podmiejskich (Berg van den et al. 1982; Więcław-Michniewska 2011; Zborowski, Chaberko, Kretowicz 2011). Do suburbiów migrują głównie młode osoby, które albo już posiadają dzieci, albo dążą do powiększenia rodziny. W konsekwencji obserwujemy przyrost rzeczywisty ludności na tych terenach.

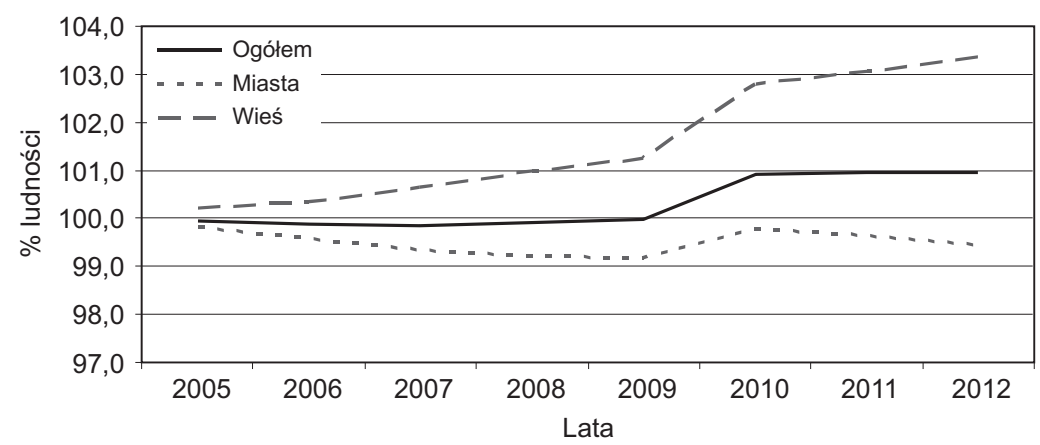

Ryc. 1. Dynamika zmian liczby ludności w Polsce w latach 2004-2012 Źródło: opracowanie własne na podstawie danych GUS.

Analiza danych na poziomie gmin wykazała nierównomierny rozwój demograficzny kraju. Polska dzieli się na dwa typy obszarów: 1) o przyroście liczby ludności, 2) o ubytku liczby ludności (ryc. 2). Wzrost liczby ludności w latach 2004-2012 zaobserwowano w strefach podmiejskich dużych miast (np. Warszawy, Poznania, Trójmiasta, Krakowa, Bydgoszczy, Torunia i Wrocławia). Wzrost ten wynikał głównie z rozwoju procesów 


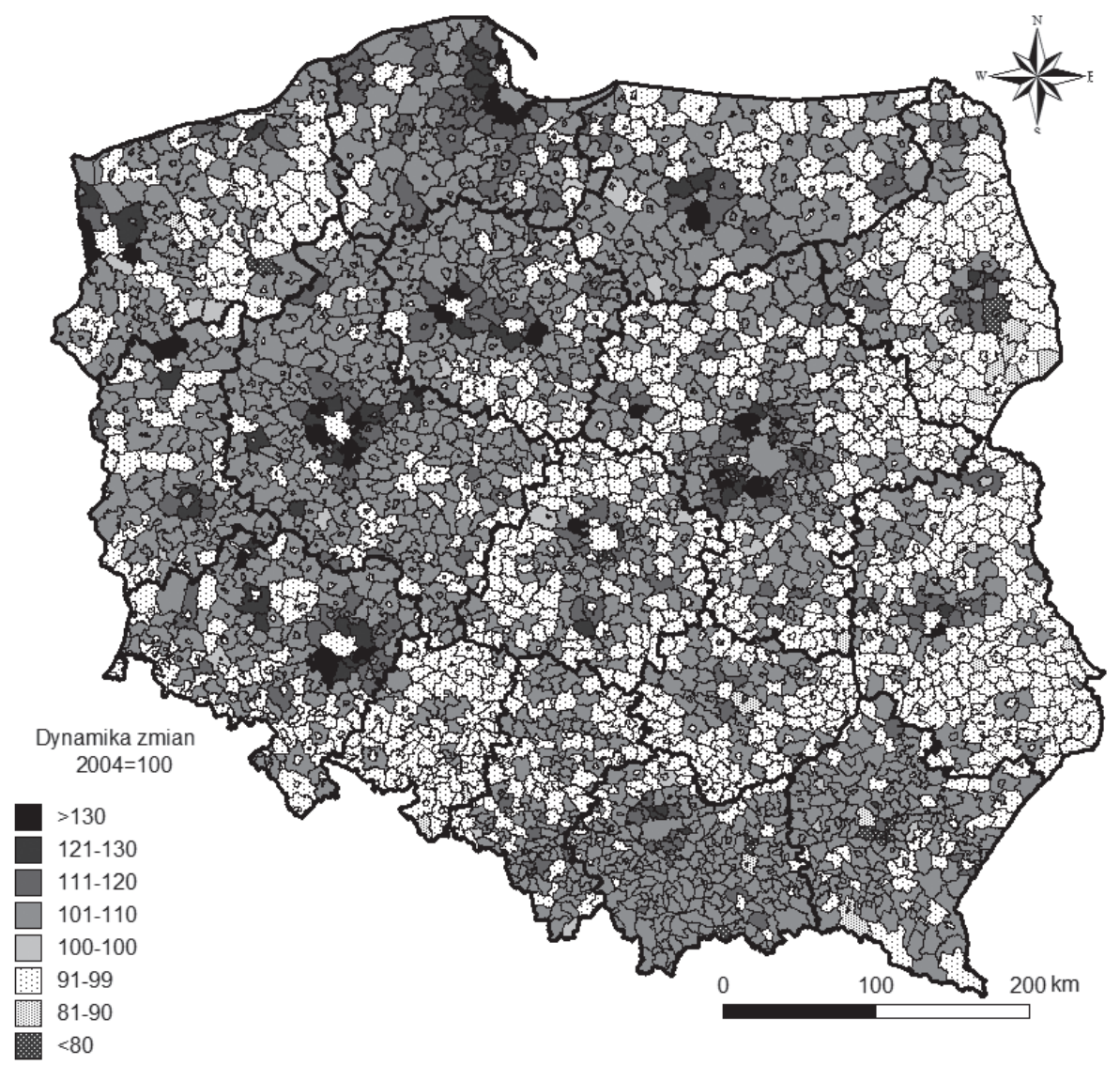

Ryc. 2. Dynamika liczby ludności w latach 2004-2012 wg gmin

Źródło: opracowanie własne na podstawie danych GUS.

suburbanizacji i napływu młodej ludności z miast centralnych. Warto nadmienić, iż strefach peryferyjnych dużych ośrodków miejskich zarysowuje się również tendencja do osiedlania się ludności spoza województwa właściwego dla danego miasta wojewódzkiego, co jest najbardziej widoczne w przypadku Warszawy, Krakowa i Poznania (Raźniak 2015). Przyrost liczby ludności wystąpił również na terenach, które tradycyjnie charakteryzowały się wysokimi wartościami przyrostu naturalnego, tj. w województwach: małopolskim, podkarpackim i pomorskim. Natomiast ubytek rzeczywisty ludności odnotowano na peryferiach Polski wzdłuż wschodniej granicy. Obszary depopulacji zlokalizowane były również na terenach wiejskich, które leżały poza strefą obszarów metropolitalnych oraz stolic województw, np. w województwach: łódzkim, mazowieckim czy świętokrzyskim. Depopulacją objęte było prawie całe województwo opolskie oraz Konurbacja Górnośląska, która w wyniku procesu restrukturyzacji zatraciła funkcje i stała się obszarem dotkniętym dużym bezrobociem strukturalnym 
i problemami społecznymi (Runge 2004; 2011; 2016; Runge et al. 2014; Sitek et al. 2013; Sobala-Gwosdz 2010) mimo wysokiego jak na warunki polskie poziomu bezpieczeństwa społecznego (Raźniak 2012; Raźniak, Winiarczyk-Raźniak 2014). W konsekwencji ludność z konurbacji zaczęła się przenosić do lepiej gospodarczo rozwiniętych obszarów w Polsce lub emigrować.

\section{Skala wyjazdów za granicę Polaków na pobyt czasowy i stały w latach 2004-2012}

Aby określić rolę emigracji w kształtowaniu przestrzennych układów zaludnienia, warto się najpierw zastanowić, jaka jest skala poakcesyjnych migracji Polaków oraz z których regionów wyjechało najwięcej osób. Podanie rzeczywistej liczby poakcesyjnych emigrantów jest zadaniem bardzo trudnym. Nie ma w pełni wiarygodnego źródła, z którego można uzyskać tego typu informacje. W świetle polskiej nomenklatury GUS migrantem jest osoba, która dopełniła obowiązku meldunkowego i zgłosiła fakt wyjazdu w gminnym biurze meldunkowym (Zborowski, Gałka 2008). W rzeczywistości takich osób jest stosunkowo niewiele, a liczby dotyczące zwłaszcza migracji czasowych są bardzo zaniżone. Niemniej jednak dane GUS są jednymi z nielicznych danych o migracjach zagranicznych Polaków i pozwalają na analizy na tak szczegółowym poziomie.

Jednym z mierników określających liczbę Polaków, którzy wyjechali z Polski, są szacunkowe dane GUS dotyczące tzw. zasobów imigracyjnych, określające liczbę obywateli polskich przebywających czasowo poza granicami kraju powyżej trzech miesięcy. Dane te nie obejmują z definicji emigracji sezonowej Polaków. W ciągu ostatnich kilku lat liczba Polaków czasowo przebywających za granicą zmieniała się i wynosiła od $1 \mathrm{mln}$ osób w 2004 r. do ponad 2 mln w 2011 r. Według szacunków GUS najwięcej Polaków czasowo przebywało za granicą w 2007 r., bo aż 2,3 mln osób (ryc. 3). Od tamtego roku ich liczba zaczęła spadać ze względu na kryzys ekonomiczny, który rozpoczął się w Stanach Zjednoczonych pod koniec 2008 r., a który do Europy dotarł z początkiem 2009 r. W latach kryzysu ekonomicznego liczba emigrantów czasowych kształtowała się na poziomie ok. 2,1 mln, a od 2011 r. ich liczba zaczęła znów rosnąć.

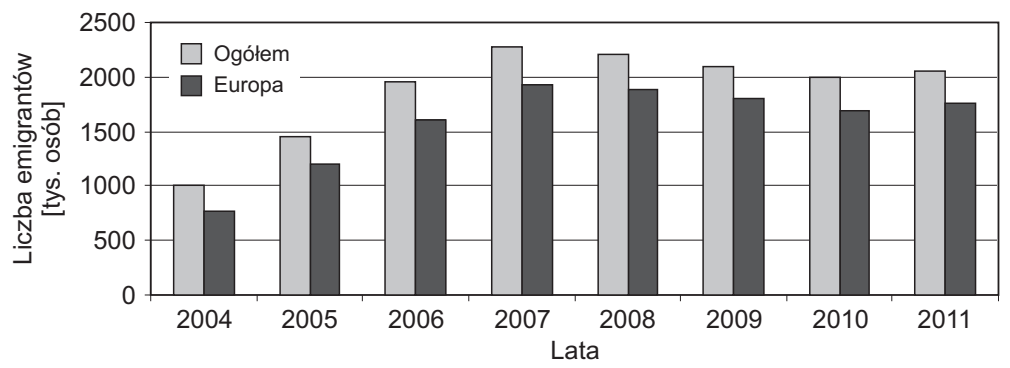

Ryc. 3. Liczba emigrantów czasowych z Polski w latach 2004-2011 Źródło: opracowanie własne na podstawie danych GUS. 
Dynamikę analizowanego zjawiska migracji zagranicznych w Polsce możemy prześledzić także na podstawie materiałów GUS odnoszących się do oficjalnej rejestracji wymeldowań na pobyt stały. Materiały te niewątpliwie obejmują niewielką część faktycznego stanu. Mają jednak pewne zalety w stosunku do innych metod dochodzeń statystycznych. Dotyczą one tej grupy osób, która postanowiła ustabilizować swoje życie poza granicami kraju, co nie tylko pociąga za sobą skutki natury prawnej, ale też znamionuje się znaczną trwałością działań, w przeciwieństwie do pozostałych form migracji (Zborowski, Gałka 2008). Ważne jest również to, że na podstawie danych o migracjach za granicę na pobyt stały można uchwycić tendencję i regionalne układy zmian migracji w Polsce (Śleszyński 2006).

Porównując dane o liczbie emigrantów zagranicznych na pobyt stały w latach 20042012, możemy zauważyć podobną tendencję jak w przypadku emigrantów czasowych (ryc. 4). Według danych GUS liczba osób wyjeżdżających na stałe z Polski zaczęła rosnać dopiero dwa lata od akcesji Polski do Unii Europejskiej, co wynikało ze strategii migracyjnych podejmowanych przez emigrantów i procesu zwanego łańcuchem migracyjnym (Gałka 2012; Hołda et al. 2011; Sakson 2001).

Mechanizm tego procesu polega na tym, że w pierwszej kolejności za granicę wyjeżdżają ludzie młodzi, którzy są najbardziej skłonni do ryzyka (Grabowska-Lusińska, Okólski 2009). Następnie, po zapoznaniu się z warunkami życia i pracy w nowym kraju, zachęcają do przyjazdu pozostałych członków rodziny lub znajomych. Inną przyczyną gwałtownego wzrostu wymeldowań z pobytu stałego było niekorzystne prawo podatkowe dla osób zameldowanych na stałe w Polsce, a zatrudnionych za granicą. Po zmianie prawa podatkowego, czyli od 2007 r., zaobserwowano spadek wymeldowań Polaków za granicę. Niekorzystnie przedstawia się natomiast sytuacja w kolejnych latach. Otóż od 2010 r., po kryzysie ekonomicznym, ponownie wzrosła liczba wyjazdów na pobyt stały z Polski, które w 2012 r. wyniosły 21, 2 tys.

Dane GUS dotyczące emigracji na pobyt stały pozwalają na ukazanie regionalnych różnic w liczbie wyjazdów za granicę (dane dotyczące emigracji czasowej nie są dostępne w układach regionalnych i lokalnych). Analiza wyjazdów w układach regionalnych

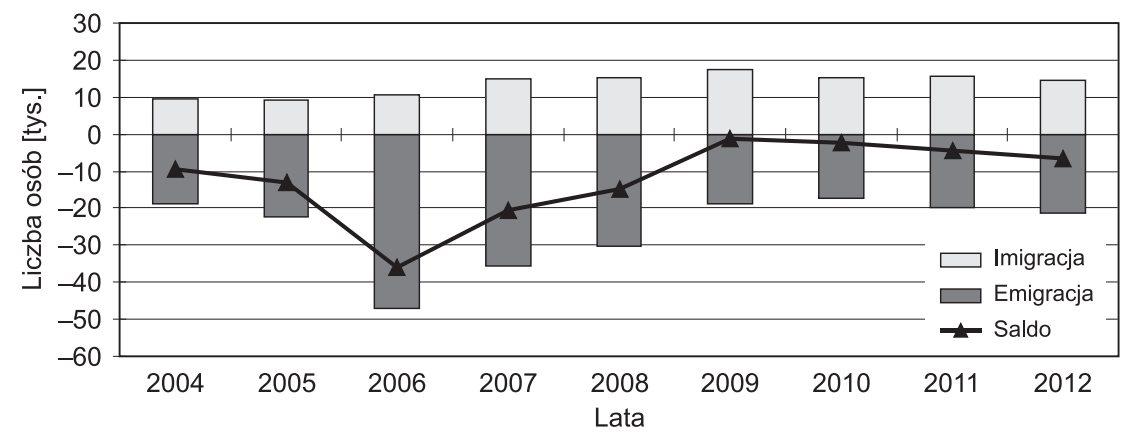

Ryc. 4. Migracje zagraniczne na pobyt stały z/do Polski w latach 2004-2012 Źródło: opracowanie własne na podstawie danych GUS. 
wykazała, że niezmiennie głównymi regionami wysyłającymi za granicę emigrantów na pobyt stały były województwa śląskie, opolskie i dolnośląskie, z których wyjechało najwięcej osób w latach 2004-2012 (ryc. 5). Odsetek wyjazdów był najwyższy z województwa śląskiego i opolskiego (ponad 12\%). Natomiast najmniejszy udział w wyjazdach na stałe odnotowano w województwach charakteryzujących się brakiem tradycji migracyjnych, przeważnie rolniczym charakterem oraz zaawansowanymi procesami starzenia się ludności (np. województwa lubelskie i świętokrzyskie) oraz w województwach przygranicznych, tj. zachodniopomorskim i lubuskim, gdzie ludność bardzo często podejmowała zatrudnienie w miejscowościach tuż za niemiecką granicą i nie musiała zmieniać swojego miejsca zamieszkania w Polsce (tzn. wymeldowywać się z Polski).

Skala problemu emigracji Polaków uwidoczniła się dopiero na niższym poziomie agregacji - na poziomie gmin. Po akcesji Polski do Unii Europejskiej nasiliła się emigracja za granicę przeważnie z gmin wiejskich położonych w województwach o niskim

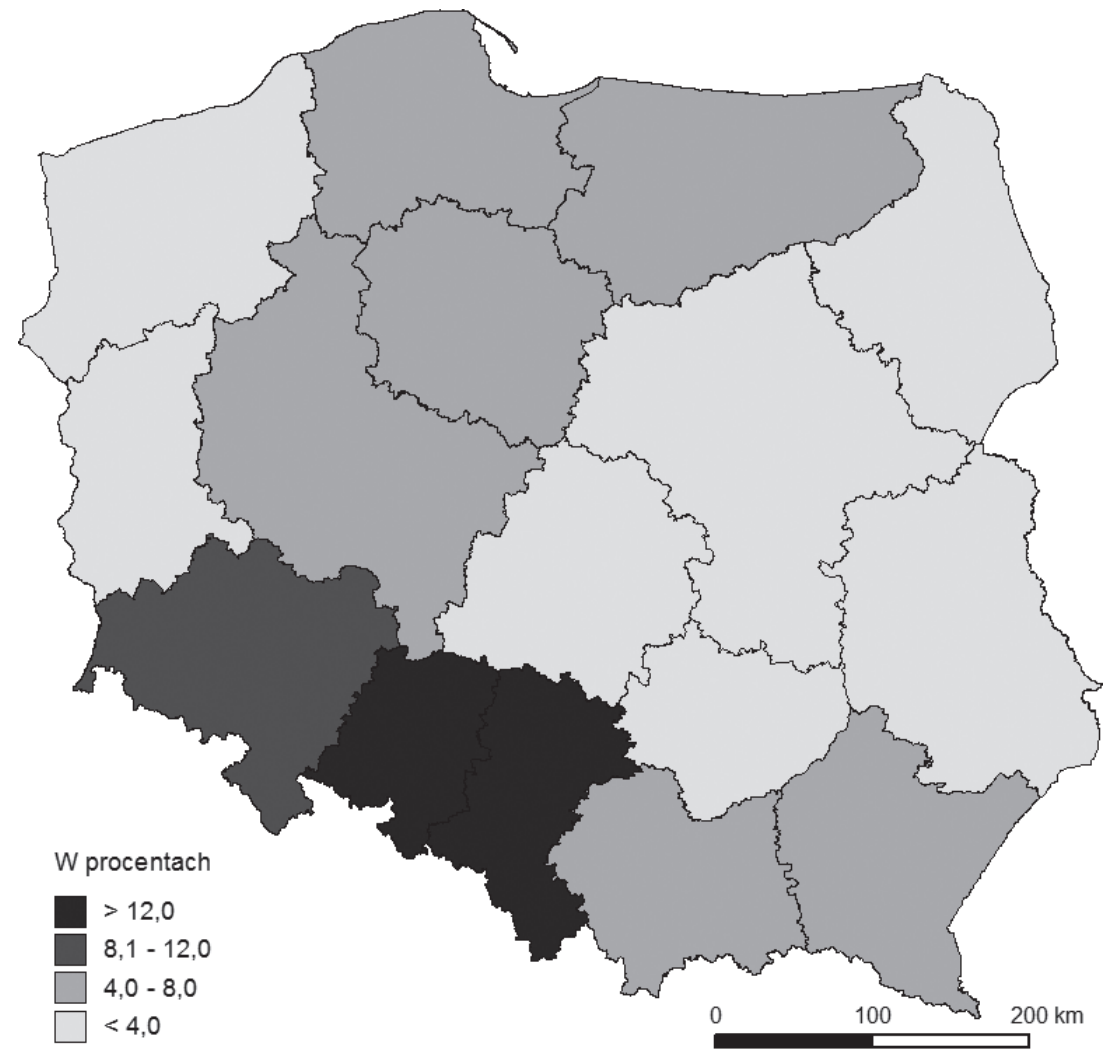

Ryc. 5. Odsetek emigrantów zagranicznych z województw w ogólnej liczbie wyjazdów na pobyt stały za granicę w latach 2004-2012 (średnia)

Źródło: opracowanie własne na podstawie danych GUS. 
poziomie rozwoju gospodarczego (gminy dolnośląskie), położonych peryferyjnie w stosunku do głównych miast kraju (np. gminy lubelskie) oraz o silnych więziach migracyjnych (np. gminy opolskie i śląskie) (ryc. 6). Natężenie wyjazdów wyniosło w niektórych gminach ponad 9\%. Migracje zagraniczne były sporadyczne w gminach położonych wokół Warszawy. Wysoki poziom rozwoju gospodarczego stolicy, możliwość znalezienia tam dobrze płatnej pracy są czynnikami przyciągającymi nie tylko okoliczną ludność, ale również mieszkańców innych miejscowości położonych w jej strefie podmiejskiej oraz w strefie dojazdów do pracy. Wyjazdy nie wystąpiły również w gminach położonych w województwie zachodniopomorskim, gdzie sytuacja ekonomiczna jest bardzo niekorzystna ze względu na m.in. słabo rozwinięty rynek pracy, skutki transformacji systemowej po 1989 r., np. upadek PGR-ów, oraz ze względu na brak rejestrowanych wyjazdów za granicę ludności, która pracuje głównie w Niemczech. Jest to także jeden z obszarów o największym odsetku osób bezrobotnych (ryc. 7), w tym długotrwale bezrobotnych (Gałka 2011).

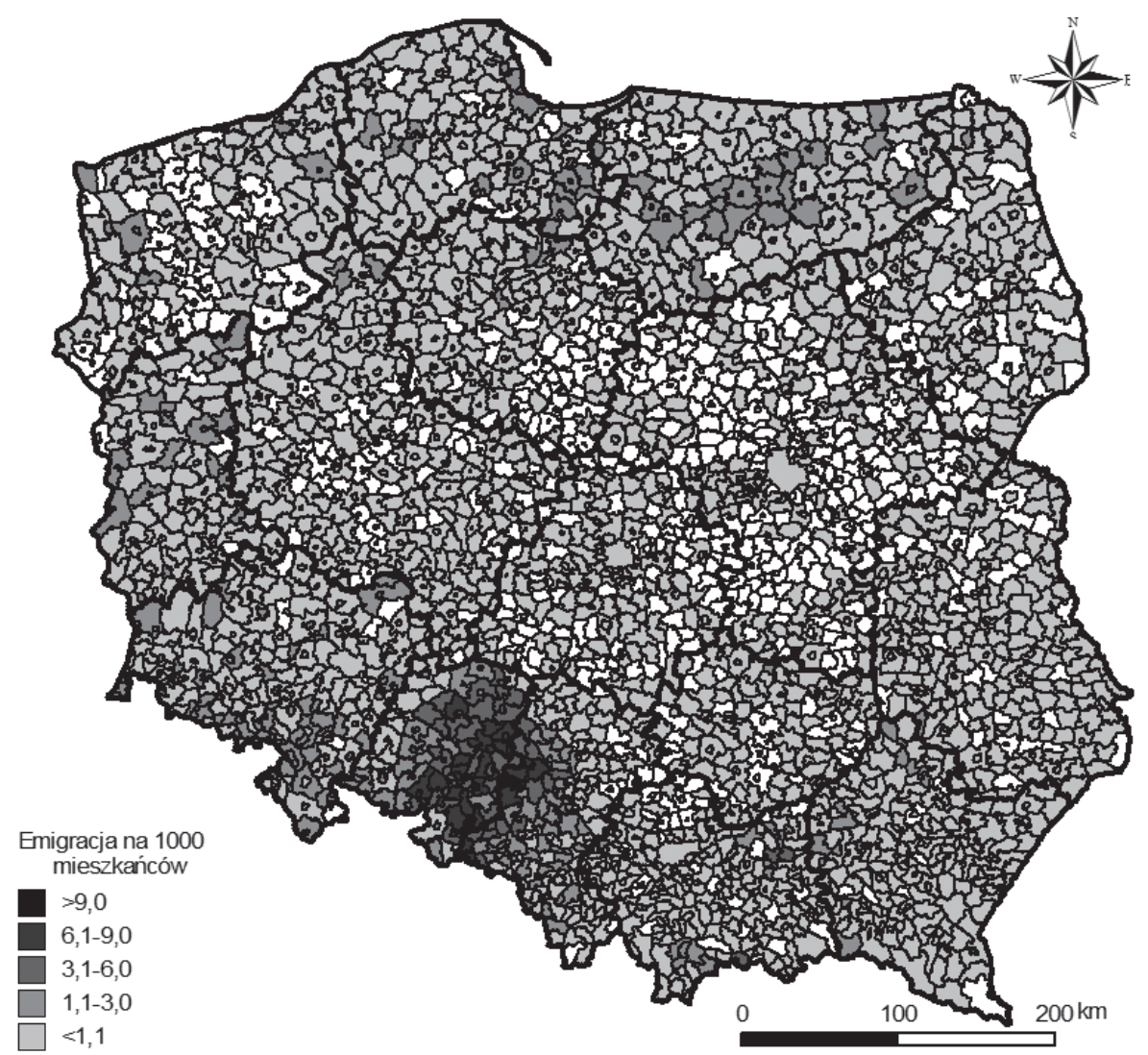

Ryc. 6. Natężenie emigracji na stałe z Polski wg gmin (średnia dla lat 2004-2012)

Źródło: opracowanie własne na podstawie danych GUS. 


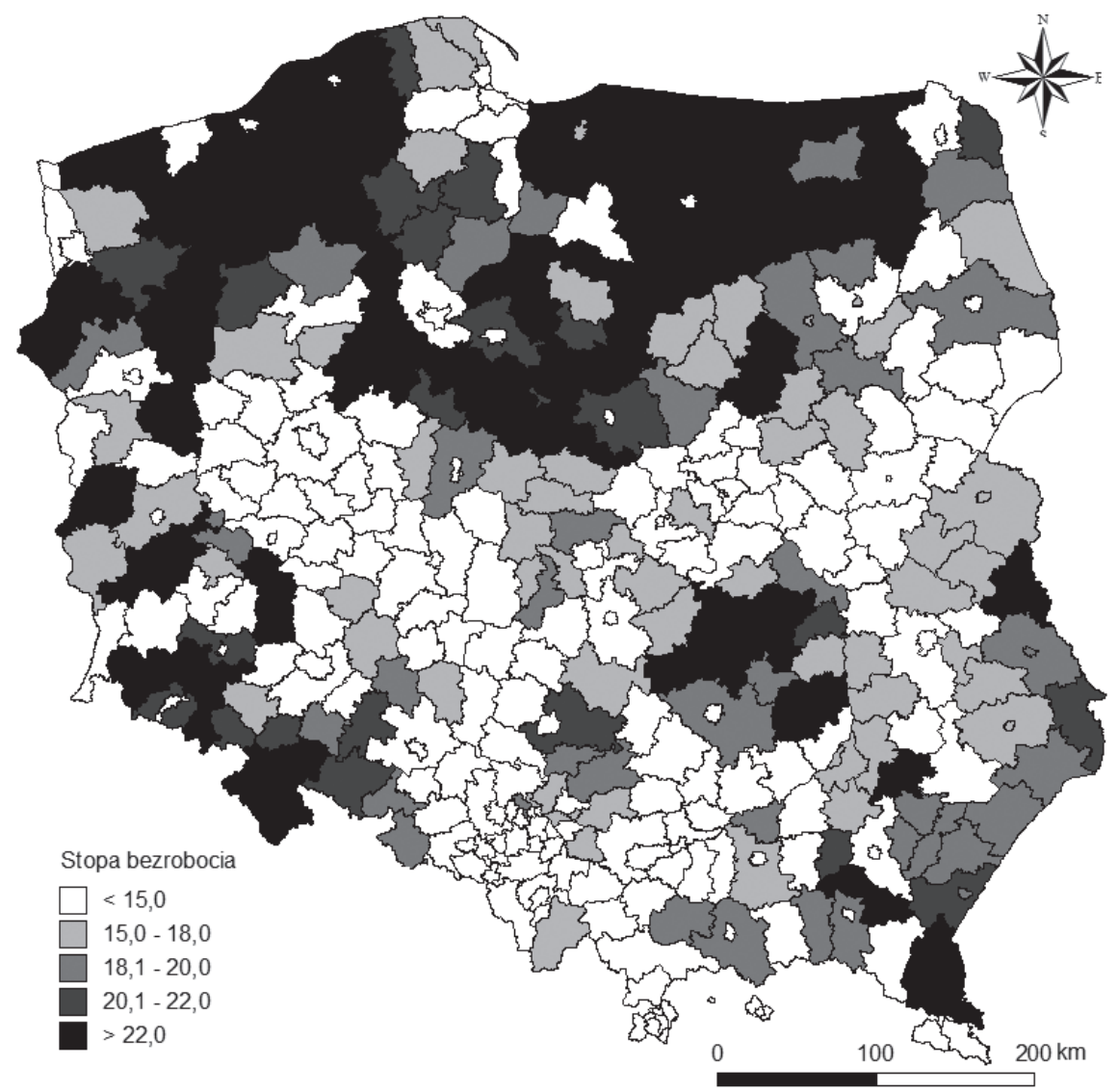

Ryc. 7. Stopa bezrobocia wg powiatów w 2012 r.

Źródło: opracowanie własne na podstawie danych GUS.

Dodatkowo gminy, z których nie odnotowano wymeldowań w badanym czasie, były rozsiane w województwach Polski wschodniej (np. miejscowości Podedwórze, Dębowa Kłoda), które charakteryzują się wysokim poziomem starzenia się populacji (Kurek 2008).

\section{Wpływ migracji zagranicznych na zmiany regionalnych układów zaludnienia}

Przeprowadzona typologia ruchu naturalnego i salda migracji zagranicznych na pobyt stały dla województw wykazała większą rolę ruchu naturalnego w kształtowaniu rozwoju demograficznego w większości przebadanych jednostek. Według przeprowadzonej typologii dla uśrednionych wartości z lat 2004-2012 Polska należała do typu A (przewaga przyrostu naturalnego nad ujemnym saldem migracji zagranicznych). 
Do tego typu należały również województwa: małopolskie, podkarpackie, lubuskie, wielkopolskie, zachodniopomorskie, kujawsko-pomorskie, pomorskie, warmińsko-mazurskie. Województwo mazowieckie należało do typu B, który oznacza, że wśród dodatnich wartości obu zmiennych przeważa przyrost naturalny ludności. Z kolei województwa: lubelskie, podlaskie, świętokrzyskie, dolnośląskie i łódzkie należały do typu F, gdzie ubytek naturalny ludności przewyższał ubytek migracyjny. Pozostałe dwa województwa, tj. śląskie i opolskie, należały do typu G - ubytek migracyjny dominował nad ubytkiem naturalnym ludności. W konsekwencji następował spadek liczby ludności na tych terenach.

Aby zbadać wpływ migracji zagranicznych ludności w kształtowaniu zaludnienia w skali lokalnej, przeprowadzono dodatkową typologię na poziomie gmin. Z badań wynika, że w grupie typów określających przyrost liczby ludności (od A do D) najlicz-

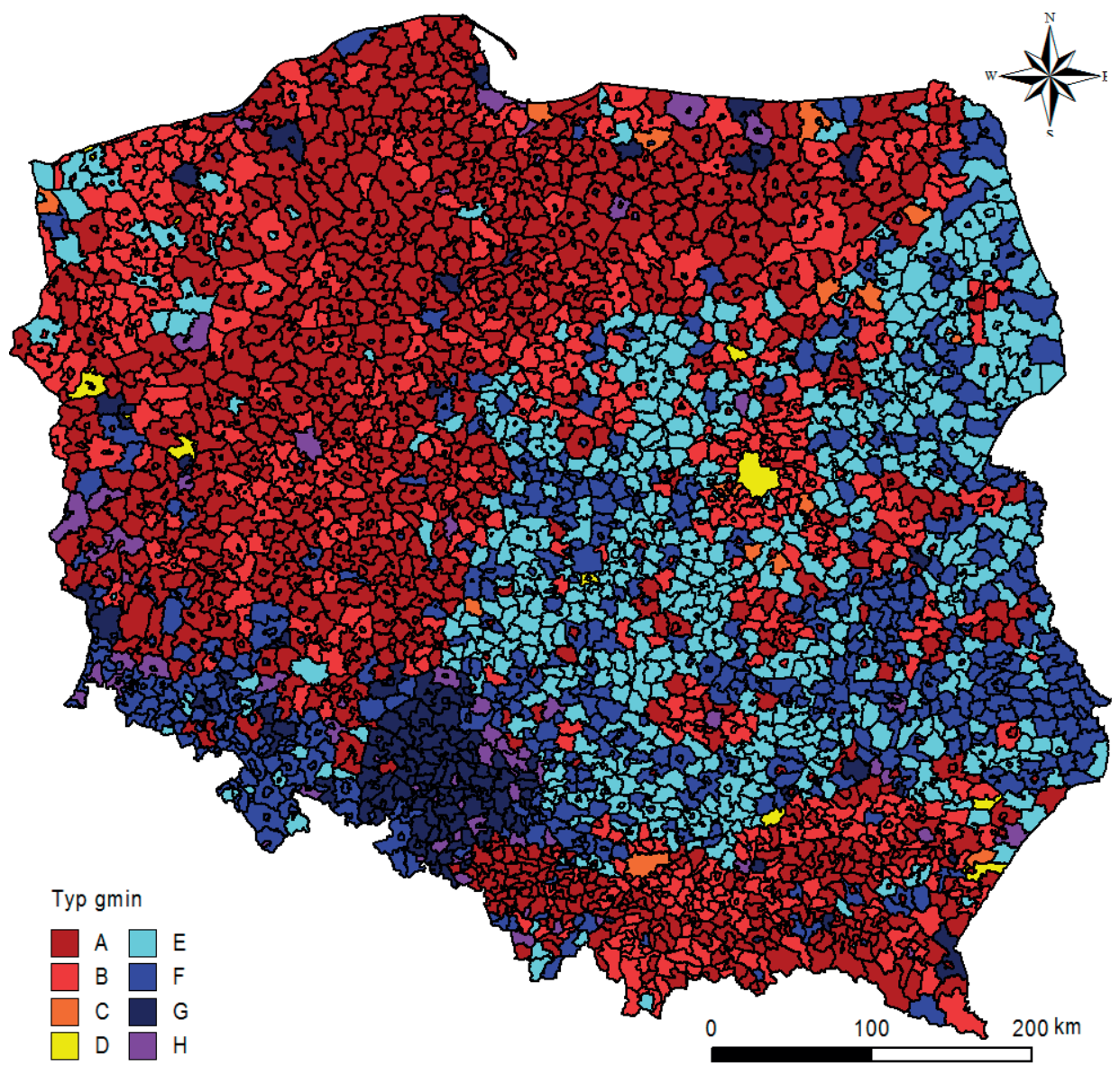

Ryc. 8. Typologia ruchu naturalnego i salda migracji zagranicznych wg gmin w latach 2004-2012 (średnia) Źródło: opracowanie własne na podstawie danych GUS. 
niejsze były typy A (przyrost naturalny rekompensuje straty spowodowane ujemnym saldem migracji zagranicznych) oraz B (przyrost naturalny wyższy od dodatniego salda migracji zagranicznych). Typ A wystąpił przeważnie w gminach województw Polski północno-zachodniej (wielkopolskim, kujawsko-pomorskim, pomorskim i warmińsko-mazurskim), natomiast typ B wystąpił w gminach województwa małopolskiego i północnej części województwa podkarpackiego. Z kolei typy C (dodatnie saldo migracji zagranicznych wyższe od przyrostu naturalnego) i D (dodatnie saldo migracji zagranicznych wyższe od ubytku naturalnego) były nieliczne i wystąpiły w gminach rozproszonych po całym kraju. Warto dodać, że w typie C znalazł się Kraków, gdzie na wzrost zaludnienia wpływało głównie dodatnie saldo migracji zagranicznych. Natomiast do typu D zaliczono Warszawę, w której także dodatnie saldo migracji zagranicznych rekompensowało straty spowodowane ubytkiem naturalnym ludności.

Analiza wykazała, że w pasie biegnącym od województwa dolnośląskiego (zwłaszcza od jego południowej części) poprzez województwa: opolskie, śląskie, świętokrzyskie, łódzkie, lubelskie do podlaskiego zdecydowana większość gmin należała do typów charakteryzujących się ubytkiem liczby ludności: E, F i G. Przy tym w gminach województwa dolnośląskiego przeważał typ F (ujemne saldo migracji zagranicznych było niższe od ubytku naturalnego), niemal wszystkie gminy województwa opolskiego należały do typu G (ujemne saldo migracji zagranicznych było wyższe od ubytku naturalnego). Z kolei w gminach województw Polski środkowej i wschodniej (świętokrzyskiego, łódzkiego, mazowieckiego - poza obszarem metropolitalnym Warszawy, lubelskiego i podlaskiego) obok typów F duża liczba jednostek należała do typu E, w których saldo migracji zagranicznych było dodatnie, jednak nie na tyle wysokie, aby rekompensować straty ludności spowodowane ubytkiem naturalnym ludności.

Przeprowadzona typologia dla wyróżnionych dodatkowo trzech podokresów wykazała niewielkie zmiany rozmieszczenia przestrzennego wyróżnionych typów gmin.

\section{Zmiany regionalnych układów zaludnienia w latach 2004-2012}

Aby ukazać dynamiczny wpływ poszczególnych zmiennych w kształtowaniu przyrostu liczby ludności, opracowano klasyfikację zmienności typów w latach 2004-2012. W sumie wyróżniono sześć typów:

- typ progresywny - charakteryzujący miasta, w których w pierwszym okresie (2004-2006) wystąpił ubytek liczby ludności (E, F, G, H), a w następnych etapach (2007-2009 i 2010-2012) nastąpił przyrost liczby ludności (A, B, C, D);

- typ stagnujący progresywny - w badanym okresie nie zaszły żadne zmiany lub zmiana wystąpiła w obrębie typów opisujących przyrost liczby ludności (A, B, C, D);

- typ regresywny - zmiana z typów charakteryzujących przyrost liczby ludności (A, B, C, D) na typy opisujące ubytek liczby ludności (E, F, G, H);

- typ stagnujący regresywny - w badanym okresie nie zaszły żadne zmiany lub zmiana wystąpiła w obrębie typów opisujących ubytek liczby ludności (E, F, G, H); 
- typ przejściowo regresywny - przyrost liczby ludności (A, B, C lub D) odnotowano w pierwszym i trzecim okresie, a w drugim okresie nastąpił ubytek liczby ludności (E, F, G lub H);

- typ przejściowo progresywny - ubytek liczby ludności odnotowano w pierwszym i trzecim okresie (E, F, G lub H), a przyrost liczby ludności w drugim okresie (A, B, C lub D).

Z tak opracowanej klasyfikacji wynika, że zdecydowana większość gmin została zaliczona do typu stagnującego progresywnego $(39,4 \%)$, bo systematycznie odnotowywały przyrost liczby ludności. Były to gminy położone na terenach charakteryzujących się wysokim przyrostem naturalnym (np. województwo pomorskie, małopolskie, strefy podmiejskie dużych miast) (ryc. 9). Kolejne 33\% jednostek zaliczono do typu stagnującego regresywnego, co oznaczało konsekwentne wyludnianie terenów wskutek ujemnego salda migracji i/lub ubytku naturalnego ludności. Tereny te pokryły się z wcześniej wyróżnionymi typami F i G ciągnącymi się pasem od województwa dolnośląskiego

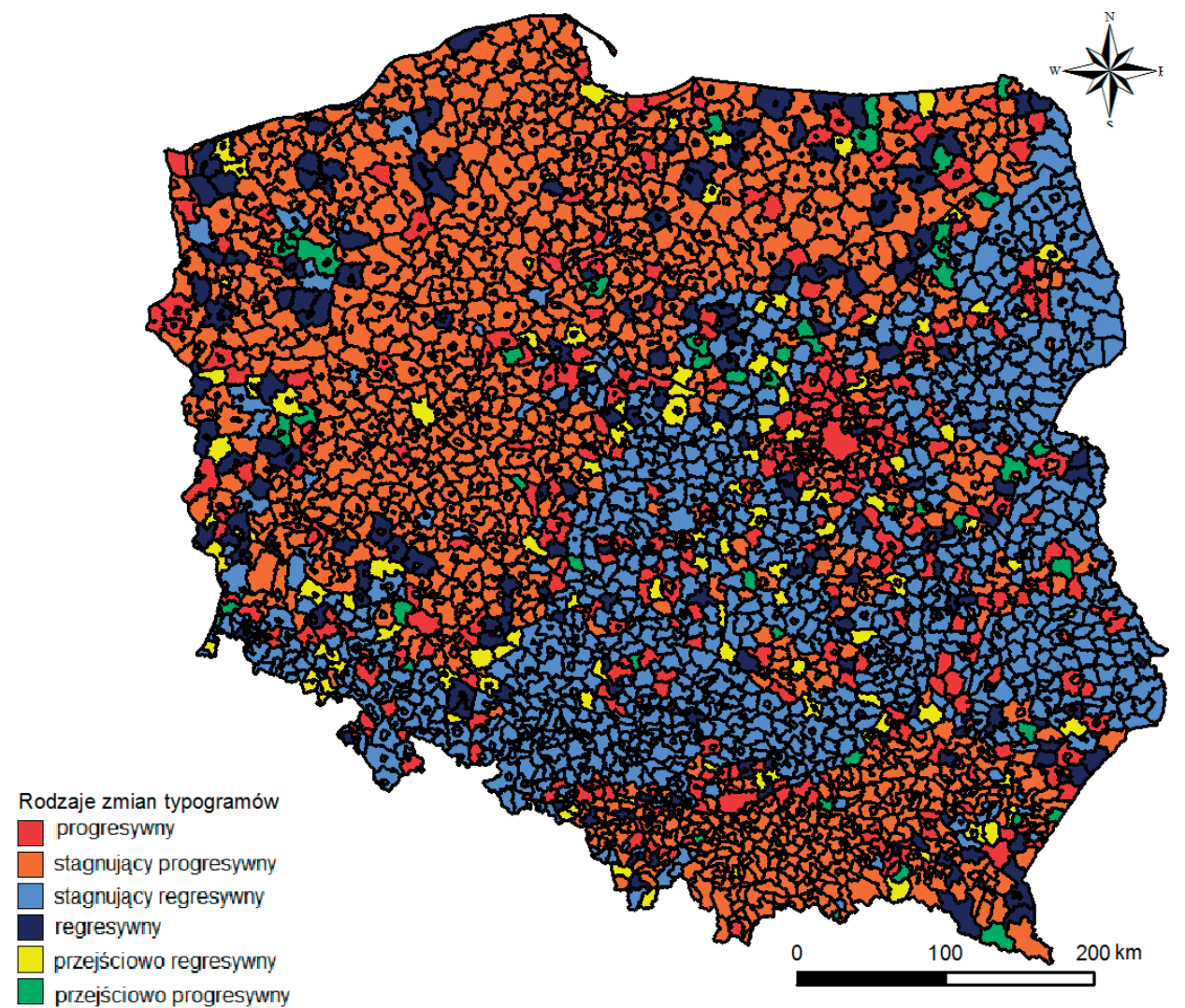

Ryc. 9. Typologia zmian typogramów wg gmin w latach 2004-2012

Źródło: opracowanie własne na podstawie danych GUS. 
poprzez centralną Polskę do Polski wschodniej (województwa lubelskie i podlaskie). Z kolei do typu progresywnego zaliczono $13,1 \%$ gmin i były to przeważnie gminy leżące w obrębie obszarów metropolitalnych dużych miast. Najkorzystniej pod tym względem wypada Warszawa i jej strefa podmiejska, która w badanym czasie odnotowała przyrost liczby ludności. Natomiast nieliczne gminy zostały zaliczone do typu regresywnego oraz typów przejściowych (łącznie 14,5\%).

\section{Podsumowanie}

Z przeprowadzonych badań wynika, że migracje zagraniczne ludności miały wpływ na sytuację demograficzną Polski, zwłaszcza na kształtowanie lokalnych układów zaludnienia. Wpływ był pozytywny (wzrost zaludnienia) lub negatywny (spadek zaludnienia). Wpływ migracji zagranicznych ludności na pobyt stały był pozytywny w przypadku przewagi dodatniego salda migracji zagranicznych nad przyrostem/ ubytkiem naturalnym ludności, a także w przypadku występowania dodatniego wyniku bilansu przemieszczeń zagranicznych ludności w danej jednostce (typ E). Niestety tylko w nielicznych gminach przeważało dodatnie saldo migracji zagranicznych nad przyrostem/ubytkiem naturalnym ludności (typy C lub D). Taka sytuacja miała miejsce m.in. w przypadku Warszawy i Krakowa. Wynikało to z korzystnej sytuacji ekonomicznej miast i z przyciąganiem ludności z zagranicy (cudzoziemców oraz reemigrantów). Zdecydowanie więcej gmin należało do typu B, w którym pomimo dodatniego salda migracji zagranicznych to przyrost naturalny ludności decydował o wzroście zaludnienia. Gminy te wystąpiły przede wszystkim w województwach małopolskim i zachodniopomorskim. Z kolei w gminach Polski środkowej i wschodniej o ubytku liczby ludności decyduje bardziej ubytek niż saldo migracji, które było dodatnie w badanych latach.

Negatywny wpływ migracji zagranicznych na pobyt stały na zmiany zaludnienia odnotowano w przypadku przewagi ujemnego salda migracji zagranicznych nad przyrostem/ubytkiem naturalnym, a także w przypadku występowania ujemnego wyniku bilansu przemieszczeń zagranicznych ludności w danej jednostce. Z badań wynika, że w zdecydowanej większości gmin województw Polski północnej i zachodniej oraz południowej (wielkopolskiego, kujawsko-pomorskiego, pomorskiego, warmińsko-mazurskiego i podkarpackiego) to głównie ruch naturalny rekompensował ujemny bilans migracji zagranicznych na pobyt stały. Ponadto ujemne saldo migracji zagranicznych na pobyt stały pogłębiało procesy depopulacji w gminach województwa opolskiego, a także na obszarze od województwa dolnośląskiego po wschodnie tereny kraju.

Podsumowując, można wysunąć wniosek, że migracje zagraniczne ludności będą w dalszym ciągu wpływać na zmiany zaludnienia Polski. Najbardziej korzystny wpływ będzie zauważalny w gospodarczo rozwijających się dużych miastach (takich jak Warszawa i Kraków), a także w gminach wiejskich, w których będą występowały migracje powrotne, np. w województwie małopolskim (migracje powrotne głównie ze Stanów Zjednoczonych). Z kolei w gminach, w których struktura demograficzna od lat jest 
niekorzystna i proces starzenia się ludności przybiera na sile, nawet dodatnie saldo migracji zagranicznych nie będzie w stanie zrekompensować strat związanych z ubytkiem naturalnym ludności (pod warunkiem utrzymywania się imigracji na obecnym poziomie). Niestety depopulacja województwa opolskiego na skutek ujemnego salda migracji zagranicznych będzie nadal postępować.

Warto podkreślić, że niekorzystne trendy migracyjne można odwrócić poprzez ograniczenie powodów, dla których ludność wyjeżdża z Polski (np. podniesienie płac), a także poprzez stworzenie warunków zachęcających zarówno Polaków przebywających za granicą, jak też obcokrajowców do przyjazdu do Polski i osiedlania się tu na stałe.

\section{Bibliografia}

Berg L. van den, Drewett R., Klassen L., Rossi A., Vijverberg C., 1982, Urban Europe: A study of growth and decline, Pergamon, Oxford.

Długosz Z., 2012, Wybrane przestrzenne aspekty trwatych migracji zagranicznych ludności w Polsce w okresie transformacji, „Zeszyty Naukowe Wydziałowe UE w Katowicach. Studia Ekonomiczne” nr 98.

Drinkwater S., Eade J., Garapich M.P., 2006, Class and ethnicity - Polish migrants in London, CRONEM, University of Surrey, Surrey.

Fihel A., Kaczmarczyk P., 2008, Wspótczesne migracje z Polski - skala, struktura oraz próba interpretacji, [w:] Kaczmarczyk P., Tyrowicz I. (red.), Wspótczesne procesy migracyjne w Polsce a aktywność organizacji pozarzadowych w obszarach powiazanych z rynkiem pracy, Fundacja Inicjatyw Społeczno-Ekonomicznych, Warszawa.

Gałązka A., 2007, Przestrzenne zróżnicowanie procesów demograficznych w Polsce w 2006 r. na tle zmian okresu 2002-2006, [w:] Sytuacja demograficzna Polski. Raport 2006-2007, Rządowa Rada Ludnościowa, Warszawa.

Gałka J., 2011, Migracje Polaków do Wielkiej Brytanii po akcesji Polski do Unii Europejskiej (analiza skali i regionów pochodzenia emigrantów), [w:] Zborowski A. (red.), Człowiek, społeczeństwo, przestrzeń, Centrum Kultury Ekumenicznej, Kraków-Myczkowce.

Gałka J., 2012, Polacy w przestrzeni społecznej Londynu u progu XXI wieku, praca doktorska niepublikowana, IGIGP UJ, Kraków.

Górz B., 1994, Emigracja zarobkowa ludności wsi podhalańskich do Stanów Zjednoczonych Ameryki Pólnocnej, [w:] Górz B. (red.), Studia nad przemianami Podhala, Wydawnictwo Naukowe WSP, Kraków. Prace Monograficzne nr 172.

Grabowska-Lusińska I., Okólski M., 2009, Emigracja ostatnia?, Wydawnictwo Naukowe Scholar, Warszawa. Holzer J.Z., 2003, Demografia, PWE, Warszawa.

Hołda M., Saczuk K., Strzelecki P., Wyszyński R., 2011, Settlers and guests - Determinants of the plans of return migration from UK and Ireland to Poland in the period 2007-2009, National Bank of Poland, Warsaw.

Iglicka K., Weinar A., 2005, Wptyw rozszerzenia Unii Europejskiej na ruchy migracyjne na terenie Polski, „Raport Centrum Stosunków Międzynarodowych”.

Jędrzejczyk D., 2001, Podstawy geografii ludności, Dialog, Warszawa.

Jończy R., 2010, Migracje zagraniczne z obszarów wiejskich województwa opolskiego po akcesji Polski do Unii Europejskiej. Wybrane aspekty ekonomiczne i demograficzne, Instytut Śląski, Opole-Wrocław.

Jończy R., Rokita-Poskart D., 2012, Wptyw zagranicznych migracji zarobkowych na sytuację społeczno-demograficznq województwa opolskiego, ROPS, Opole.

Kłos B., 2006, Migracje zarobkowe Polaków do krajów Unii Europejskiej, „Infos” nr 2.

Kurek S., 2008, Typologia starzenia się ludności Polski w ujęciu przestrzennym, Wydawnictwo Naukowe Akademii Pedagogicznej, Kraków.

Raźniak P., 2012, Wptyw poziomu bezpieczeństwa społecznego na migracje ludności w Polsce, „Bezpieczeństwo. Teoria i Praktyka" 6. 
Raźniak P., 2015, Impact of selected socio-economic factors on migration patterns in Poland, „Annales Universitatis Paedagogicae Cracoviensis Studia Geographica" 9.

Raźniak P., Winiarczyk-Raźniak A., 2014, Influence of the societal security level on population migrations in Poland, „Procedia - Social and Behavioral Sciences” 120.

Runge J., 2004, Rynek pracy w miastach województwa śląskiego, [w:] Słodczyk J. (red.), Rozwój miast i zarządzanie gospodarka miejska, Uniwersytet Opolski, Opole.

Runge A., 2011, Medium-sized towns in the context of size structural changes of towns in Poland, [w:] Runge A., Kuczabski A. (eds.), Medium-sized towns of Central-Eastern Europe in the period of economic system transformation and social changes, ADNDU, Kharkiv.

Runge A., 2016, Urban agglomerations and transformations of medium-sized towns in Poland, „Environmental \& Socio-Economic Studies" 4(3).

Runge J., Kantor-Pietraga I., Krzysztofik R., Runge A., 2014, Model urbanizacji złożonych układów osadniczych w świetle procesu kurczenia się miast w Polsce - próba analizy krytycznej, [w:] Stryjakiewicz T. (red.), Kurczenie się miast w Europie Środkowo-Wschodniej, Bogucki Wydawnictwo Naukowe, Poznań.

Sakson B., 2001, Źródła pionierskiego tańcucha migracyjnego, [w:] Jaźwińska-Motylska E., Okólski M. (red.), Ludzie na huśtawce. Migracje między peryferiami Polski i Zachodu, Wydawnictwo Naukowe Scholar, Warszawa.

Sakson B., 2007, Migracje zagraniczne, [w:] Sytuacja demograficzna Polski. Raport 2006-2007, Rządowa Rada Ludnościowa, Warszawa.

Sitek S., Runge J., Kłosowski F., Runge A., Petryszyn J., Pytel S., Kurpanik M., Spórna T., Zuzańska-Żyśko E., 2013, Społeczno-gospodarcze oraz przestrzenne kierunki zmian regionalnego oraz lokalnych rynków pracy województwa śląskiego, SGP WSL, Uniwersytet Śląski, Sosnowiec.

Sobala-Gwosdz A., 2010, Badania trendów rozwojowych w województwie śląskim poprzez wyznaczenie ośrodków zrostu i obszarów stagnacji, Wojewódzki Urząd Pracy w Katowicach, Katowice.

Śleszyński P., 2006, Zmiany emigracji z Polski wedtug oficjalnych statystyk w ujęciu przestrzennym po przystapieniu Polski do Unii Europejskiej, „Biuletyn Migracyjny - Dodatek” nr 10.

Więcław-Michniewska J., 2011, Suburbanizacja w Krakowskim Obszarze Metropolitalnym, [w:] Jakóbczyk-Gryszkiewicz J. (red.), Regiony miejskie w Polsce. Dwadzieścia lat transformacji, Wydawnictwo Uniwersytetu Łódzkiego, Łódź.

Zborowski A., Chaberko T., Kretowicz P., 2011, Procesy suburbanizacji rezydencjonalnej w regionie miejskim Krakowa: przemiany społeczno-przestrzenne, [w:] Jakóbczyk-Gryszkiewicz J. (red.), Regiony miejskie w Polsce. Dwadzieścia lat transformacji, Wydawnictwo Uniwersytetu Łódzkiego, Łódź.

Zborowski A., Gałka J., 2008, Migracje stałe i czasowe z Polski po akcesji do Unii Europejskiej, [w:] Ilnicki D., Janc K. (red.), Przekształcenia regionalnych struktur funkcjonalno-przestrzennych, IGiRR UW, Wrocław. Rozprawy Naukowe Instytutu Geografii i Rozwoju Regionalnego Uniwersytetu Wrocławskiego 3.

Zdrojewski E., 2007, Migracje ludności w wieku produkcyjnym w województwach Polski północnej, [w:] Sobczak I. (red.), Czynnik demograficzny w rozwoju społeczno-gospodarczym Polski, PTD, Uniwersytet Gdański, Gdańsk.

Zdrojewski E., 2009, Migracje definitywne w Polsce. Regiony naptywowe i odptywowe, [w:] Jacewicz I. (red.), Wspótczesne problemy przemian strukturalnych przestrzeni geograficznej, Akademia Pedagogiczna, Słupsk.

Zdrojewski E., Guzińska M., 2011, Salda migracji jako podstawa typologii województw, „Zeszyty Naukowe Instytutu Ekonomii i Zarządzania” nr 15. 